\title{
POTENSI ANTIMALARIA \\ EKTRAK DIKLOROMETAN DAUN BUNGA MATAHARI (Helianthus annuus L.) SECARA IN VIVO PADA HEWAN COBA
}

\author{
Roihatul Muti'ah, Elok K.H, dan Ijro'atul B. \\ Fakultas Sains dan Teknologi UIN Maliki Malang \\ Email:mroihatul@yahoo.com
}

\begin{abstract}
Antimalaria experiment on this research aimed to know the activity of extract sunflower leaf to the growth of parasit Plasmodium berghei in mice balb/c. Mice is being infected by interaperitonial with $10^{6}$ Plasmodium berghei and divided into 5 groups of treatment, they are (1) positive control, (2) artemisin control $0,004 \mathrm{mg} / \mathrm{g} \mathrm{BB}$, , (3) extract sunflower of dose $1(0,05 \mathrm{mg} / \mathrm{g} \mathrm{BB})$, (4) extract sunflower of dose $2(0,5 \mathrm{mg} / \mathrm{g} B B)$ and extract sunflower of dose $3(5 \mathrm{mg} / \mathrm{g}$ BB). Those experiment of antimalaria activity used Peter method. The therapy is done when degree of parasitemia after infected reach 5-15\% that was counted as day -0 and it is given during 5 days. Monitoring the degree of parasitemia is done in day -0, day -1, day -2, day -3, and day -5 . The result shows that all dose of extract diklorometan sunflower can kill parasit plasmodium berghei and degree of parasitemia reached $0 \%$ in day -3 and day -4 after therapy. The statistic analysis shows that the first, second, and third doses on the positive control group have siginificant differences with $p<0.05$. on the artemism group, first, second, and third doses doesn't show significant differences with $p>0.05$. This shows that extract diklorometan having high potential as antimalaria and the effect is the same with artemism.
\end{abstract}

Keywords: antimalaria, extract diklorometan, Helianthus annus, In vivo, plasmodium berghei

\section{A. PENDAhULUAN}

Malaria merupakan penyakit menular yang sangat berbahaya dapat menyebabkan kematian, ter utama pada kelompok-kelompok yang mempunyai risiko tinggi seperti bayi, anak balita dan ibu hamil, serta kelompok usia produktif, sehingga secara langsung dapat menurunkan produktivitas kerja (Hasan, 2006).

Malaria ditemukan hampir di seluruh bagian dunia, terutama di negara-negara yang beriklim tropis dan subtropis. Penduduk yang berisiko terkena malaria berjumlah sekitar 2,3 miliar atau 41\% dari jumlah penduduk dunia. Setiap tahun, kasusnya berjumlah sekitar
300-500 juta kasus dan mengakibatkan 1,5-2,7 juta kematian, terutama di negara-negara benua Afrika (WHO, 2011)

Penyakit ini menjadi ancaman yang serius mengingat akhir-akhir ini beberapa obat yang tersedia sepetri klorokuin dan kuinin telah mengalami resistensi terhadap Plasmodium falciparum. Di Papua tiga jenis obat penyakit malaria, yaitu kloroquin, piremetamin dan sulvadoxin, saat ini sudah tidak mempan lagi (resisten) untuk mengobati pasien malaria. Belum ditemukannya obat malaria yang efektif dan tidak resisten terhadap Plasmodium falsiparum, usaha 
eksplorasi obat antimalaria untuk kehamilan baru menjadi salah satu prioritas utama, terutama yang berasal dari alam sebagai salah satu usaha eksplorasi terhadap kekayaan alam yang di miliki oleh Indonesia. Oleh karena itu perlu mencari sumber tanaman lain yang selama ini telah dipercaya oleh masyarakat untuk menyem-buhkan penyakit malaria, yang berpeluang mempunyai sifat toksik untuk dapat dikembangkan menjadi senyawa antimalaria.

Bunga Matahari (Helianthus annuus L.) selama ini dikenal sebagai tanaman hias. Selain sebagai tanaman hias, pemanfaatan bunga matahari pada bagian bunga dan biji adalah sebagai sumber minyak yang kaya asam linoleat, sedangkan bagian daun bunga matahari belum termanfaatkan secara optimal. Selama ini daun bunga matahari hanya dimanfaatkan daunnya untuk pakan ternak. Keberadaannya yang melimpah, mudah didapat dan mudah dibudidayakan inilah yang memberikan peluang tanaman ini dapat ditingkatkan nilai gunanya khususnya sebagai salah satu sumber tanaman obat.

Secara empiris daun bunga matahari telah digunakan sebagai obat antimalaria. Namun sampai saat ini masih belum ada pembuktian secara ilmiah tentang efektifitas ekstrak daun bunga matahari sebagai obat antimalaria. Pada penelitian sebelumnya telah dilaporkan bahwa daun bunga matahari yang di ekstraksi dengan pelarut diklorometan mengandung senyawa seskuiterpen lakton annuolide E, lept ocarpin, seskuiterpen heliannuols A, C, D, F, G, H, I, bisnorsesquiterpene baru, Eannuionone, dan seskuiterpen L heliannuol, helibisabonol A dan (
Macías et al, 2002), helivypolida G (Macías et al, 2004), bisnorseskuiterpen annuionones A-C dan helinorbisabone (Marcias et al, 1998), germacranolide, annuithrin, heliangolide, niveusin B and turunan etoksi (Spring, 1981). Monoterpenoid $\alpha$-pinene (Ceccarini, 2004).

Senyawa sesquiterpen telah diketahui aktif sebagai obat antimalaria sabagai contoh obat artemisin yang merupakan obat pilihan yang menempati lini pertama obat antimalaria adalah termasuk senyawa sesquiterpen. Oleh karena itu adanya kandungan senyawa sesquiterpen pada ekstrak diklorometan daun bunga matahari diduga kuat mempunyai efek antimalaria. Hal tersebut juga diperkuat denga hasil penelitian Anjum et al tahun 2005 yang menginformasinkan adanya senyawa sesquiterpen lakton dalam fraksi diklormetan daun bunga matahari setelah dilakukan identifikasi dengan spektroskopi NMR. Oleh karena itu perlu dilakukannya penelitian lebih lanjut, guna mengetahui efektifitas senyawa seskuiterpenoid yang terkandung pada ekstrak daun bunga matahari sebagai obat antimalaria. Kedepan, harapannya obat antimalaria dari daun bunga matahari ini dapat gunakan sebagai salah satu pilihan terapi antimalaria yang efektif.

\section{B. METODE PENELITIAN}

1. Desain penelitian

Penelitian eksperimental murni ini dilakukan dengan menggunakan desain Postest Only Control Group Design.

\section{Tempat dan Waktu Penelitian}

Penelitian ini dilakukan di Laboratorium Biologi Fakultas 
Uji Potensi Antimalaria Ektrak Diklorometan ...

SAINTEK UIN Maliki Malang dan Laboratorium Parasitologi Fakultas Kedokteran Universitas Brawijaya Malang pada bulan Juli s/d Desember 2011

\section{Tanaman}

Daun bunga matahari diperoleh dari daerah Batu Malang, daun dikeringkan dibawah sinar matahari dengan ditutup kain hitam selama 5 hari, kemudian diserbuk dan diekstraksi dengan metode maserasi.

\section{Hewan coba}

Penelitian ini menggunakan hewan coba mencit albino galur $\mathrm{Balb} / \mathrm{c}$ jantan, umur 8-12 minggu, berat 28-32, diambil dari Pusat Veterinaria Farma Surabaya (PUSVETMA) sejumlah 66 ekor. Mencit diberi pakan standar untuk hewan coba berupa comfeed dan minum ad libitum.

\section{Rancangan Percobaan}

Rancangan percobaan yang digunakan adalah rancangan acak lengkap. Mencit dibagi menjadi 6 kelompok perlakuan yaitu

a.Kelompok kontrol negatif adalah kelompok perlakuan tanpa infeksi $P$. berghei dengan pemberian larutan $\mathrm{CMC}$ (Carboxi Metil Cellulosa) 0,5\%

b.Kelompok kontrol positif adalah kelompok perlakuan yang di infeksi $P$. berghei tanpa terapi.

c.Kelompok Artemisin adalah kelompok perlakuan Artemisin dosis $0,04 \mathrm{mg} / \mathrm{g}$ bb sekali sehari secara per-oral.

d.Kelompok Bunga matahari 1 adalah kelompok perlakuan infeksi $P$. berghei dan diterapi ekstrak diklorometan daun bunga matahari dosis $0,05 \mathrm{mg} / \mathrm{kg}$ bb sekali sehari secara per-oral

e.Kelompok Bunga matahari 2 adalah kelompok perlakuan infeksi $P$. berghei dan diterapi ekstrak diklorometan daun bunga matahari dosis $0,5 \mathrm{mg} / \mathrm{kg}$ bb sekali sehari secara per-oral

f. Kelompok Bunga matahari 3 adalah kelompok perlakuan infeksi $P$. berghei dan dan diterapi ekstrak diklorometan daun bunga matahari dosis 5 $\mathrm{mg} / \mathrm{kg}$ bb sekali sehari secara per-oral.

Pengujian aktivitas antimalaria in vivo dilakukan dengan menggunakan metode Fitri L.E modifikasi dari metode Peter (Phillipson dan Wright). Terapi dilakukan ketika derajat parasitemia setelah infeksi mencapai $5-15 \%$ yang dihitung sebagai hari ke-0. Terapi dilakukan setiap hari selama 5 hari. Pengamatan derajat parasitemia dilakukan pada hari ke-0, hari ke-1, hari ke-2, dan hari ke-3 dan ke-5.

\section{Pembuatan Donor (Blazquez et} al, 2008)

Eritrosit yang terinfeksi parasit di resuspensikan dalam 200 $\mu$ RPMI, kemudian diinjeksikan pada mencit secara intra-peritonial. Dilakukan pengamatan parasitemia. Ketika parasitemia mencit donor telah mencapai 2,5\% maka digunakan untuk menginfeksi mencit yang lain.

\section{Inokulasi Parasit (Blazquez et} al, 2008)

Inokulasi Plasmodium berghei dilakukan secara intera peritoneal sebanyak $1 \times 10^{6}$, jika derajat parasitemia mencit donor sebesar $2,5 \%$ maka diambil darah sebesar 6,7 $\mu \mathrm{l}$, kemudian di resuspensikan dalam $200 \mu \mathrm{l}$ RPMI. Setelah dilakukan infeksi selanjutnya dilakukan peng amatan parasitemia setiap hari hingga parasitemia mencapai $5-15 \%$. kemudian dilakukan terapi obat/ ekstrak uji selama 7 hari. 


\section{Pengukuran derajat para- sitemia (Sardjono dan Fitri, 2007)}

Mula-mula dibuat hapusan darah yang dilakukan dengan cara mengambil setetes darah dari ekor mencit dengan menggunting ekor mencit dan diteteskan pada kaca benda Tetesan darah tersebut ditipiskan dengan menggunakan tepi kaca benda yang lain dan ditunggu sampai kering. Kemudian hasil hapusan ditetesi dengan methanol hingga merata dan ditunggu hingga kering. Selanjutnya dilakukan pewarnaan Giemsa dengan cara mencampurkan pewarna Giemsa dan Buffer Giemsa dengan perbandingan 1 : 9 dan diteteskan pada hapusan, ditunggu selama 20 menit, selanjutnya dibilas dengan air mengalir hingga tidak ada cat yang tersisa dan kemudian dikeringkan. Selanjutnya hapusan darah yang sudah dicat dilakukan pemeriksaan parasitemia di bawah mikroskop menggunakan pembesaran $1000 \mathrm{x}$ dengan menghitung jumlah eritrosit yang terinfeksi malaria dari 1000 eritrosit. Parasitemia merupakan jumlah eritrosit yang terinfeksi Plasmodium berghei dalam 1000 eritrosit.

Persentase penghambatan pertumbuhan parasit dihitung dengan rumus (Sardjono dan Fitri, 2007):

Inhibition(\%) $=100 \% \times($ parasitemia of control positif - parasitemia of drug $)$

Parasitemia of control positif

Parasitemia of control "Positif" diperoleh dari derajat parasitemia kelompok perlakuan yang diinfeksi Plasmodium berghei tanpa perlakuan terapi antimalaria.

Parasitemia of drug diperoleh dari derajat parasitemia kelompok per lakuan yang diinfeksi Plasmodium berghei dan diterapi obat antimalaria dan atau ekstrak tanaman percobaan.

\section{HASIL DAN PEMBAHASAN}

Uji aktivitas antimalaria pada penelitian ini bertujuan untuk mengetahui efek antimalaria ekstrak diklorometan daun bunga matahari pada mencit jantan. Bagian daun bunga matahari ini secara empiris telah diketahui berefek menyembuhkan penderita malaria. Namun sejauh ini masih belum ada pembuktian ilmiah tentang efek antimalaria daun bunga matahari tersebut.

Pengujian aktivitas antimalaria tersebut dilakukan secara in vivo pada hewan coba. Hewan coba yang digunakan adalah mencit putih jantan galur Balb/C. Alasan dipilihnya mencit sebagai hewan uji (animal model) adalah karena mencit memiliki kesetaraan taksonomi dengan manusia, seperti reaksi ter hadap penyakit maupun pengobatan, serta mempunyai kemiripan dalam hal fisiologi manusia (Coutrier, 2008). Dipilih mencit jantan adalah untuk menggambarkan aktivitas antimalaria pada manusia normal (tidak dalam kondisi hamil).

Penelitian ini menggunakan parasit Plasmodium berghei ANKA. Alasan digunakan Plasmodium berghei karena parasit ini memiliki kesamaan dengan parasit yang menginfeksi mamalia, meliputi: siklus hidup, morfologi stadium pertumbuhan, organisasi genom, metabolic pathway (Coutrier, 2008).

Aktivitas antimalaria ekstrak daun bunga matahari ditetapkan melalui pengukuran derajat parasitemia. Derajat parasitemia diperiksa mulai hari ke-0 sampai hari ke-4 pasca terapi. Pemeriksaan parasitemia hari ke-0 bertujuan untuk membuktikan 
Uji Potensi Antimalaria Ektrak Diklorometan ...

bahwa semua mencit berada dalam range derajat parasitemia yang sama pada hari akan dilakukan pengobatan. Hasil pemeriksaan derajat parasitemia disajikan pada tabel 1

Tabel 1 Rerata Derajat Parasitemia Ekstrak Daun bunga matahari

\begin{tabular}{|l|l|l|l|l|l|}
\hline \multirow{2}{*}{$\begin{array}{l}\text { Kelompok } \\
\text { Perlakuan }\end{array}$} & \multicolumn{4}{|l|}{ Rerata derajat parasitemia $(\%) \pm$ Standar Deviasi } \\
\cline { 2 - 6 } & Hari ke-0 & Hari ke-1 & Hari ke-2 & Hari ke-3 & Hari ke-4 \\
\hline Kontrol $(+)$ & 11,52 & 29,69 & 40,78 & 49,03 & 60,5 \\
\hline Artemisin & 10,71 & 5,3 & 2,93 & 0 & 0 \\
\hline Daun bunga 1 & 10,45 & 6,95 & 2,51 & 0 & 0 \\
\hline Daun bunga 2 & 9,31 & 4,27 & 7,97 & 0 & 0 \\
\hline Daun bunga 3 & 4,49 & 2,58 & 0,97 & 0 & 0 \\
\hline
\end{tabular}

Keterangan:

Kontrol positif : Infeksi Plasmodium berghei tanpa terapi

artemisin : Pemberian terapi artemisin matahari dosis $0,04 \mathrm{mg} / \mathrm{g} \mathrm{BB}$

daun bunga 1 : Pemberian terapi ekstrak daun bunga matahari dosis $0,05 \mathrm{mg} / \mathrm{g} \mathrm{BB}$

daun bunga 2 : Pemberian terapi ekstrak daun bunga matahari dosis $0,5 \mathrm{mg} / \mathrm{g} \mathrm{BB}$

daun bunga 3 : Pemberian terapi ekstrak daun bunga matahari dosis $5 \mathrm{mg} / \mathrm{g} \mathrm{BB}$

Dari Tabel 5.1 dapat dilihat hasil rata-rata derajat parasitemia untuk semua kelompok perlakuan terapi ekstrak daun bunga matahari lebih rendah dibanding kelompok kontrol positif dan telah mencapai $0 \%$ mulai hari ke-3. Dan dapat diketahui pula bahwa nilai derajat parasitemia tidak jauh berbeda dengan kelompok perlakuan artemisin, dimana pada kelompok perlakuan artemisin menunjukkan derajat parasitemia $0 \%$ pada hari ke-3 dan ke-4 demikian juga dengan kelompok perlakuan ekstrak bunga matahari. Hal tersebut juga didukung dengan hasil analisis statistik yang menunjukkan bahwa pada semua kelompok perlakuan ekstrak daun bunga matahari berbeda bermakna terhadap kelompok per lakuan kontrol positif $(p<0,05)$ mulai hari ke-2, dan tidak berbeda bermakna jika dibandingkan dengan kelompok perlakuan artemisin $(\mathrm{p}>0,05)$

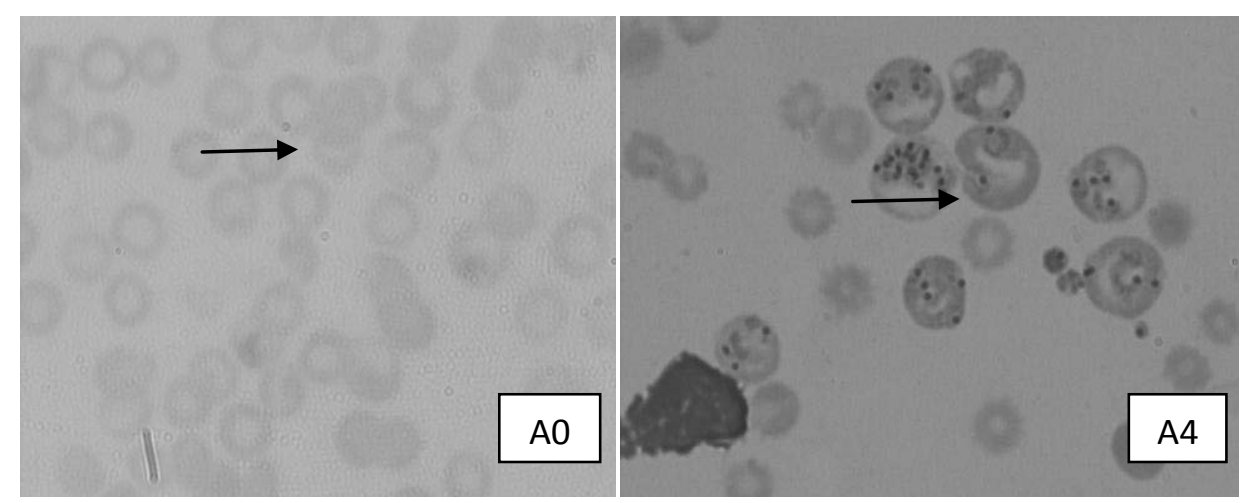

Gambar 1 Gambaran Eritrosit Terinfeksi Kelompok Kontrol (+) Tanpa Terapi pada Hari ke-0 dan Hari ke-4

Hapusan darah tipis mencit terinfeksi Plasmodium berghei dengan pengecatan Giemsa tanpa terapi hari ke-0 (A0), ke-4 (A4). Gambar pada mikroskop perbesaran 1000x.

Pada hari ke-0 (A0) terlihat dengan tanda panah. Seiring adanya gambaran eritrosit terinfeksi bertambahnya waktu trofozoid terbentuk trofozoid yang ditunjuk sebut berkembang membentuk 
skizon kemudian skizon tersebut akan ruptur dan dilanjutkan dengan penginfeksian parasit Plasmodium berghei ke eritrosit yang lain. Sehingga tampak jelas terlihat Pada hari ke-4 sebagian besar eritrosit telah terinfeksi parasit, bentuk skizon mature ditunjuk dengan tanda panah (A4)

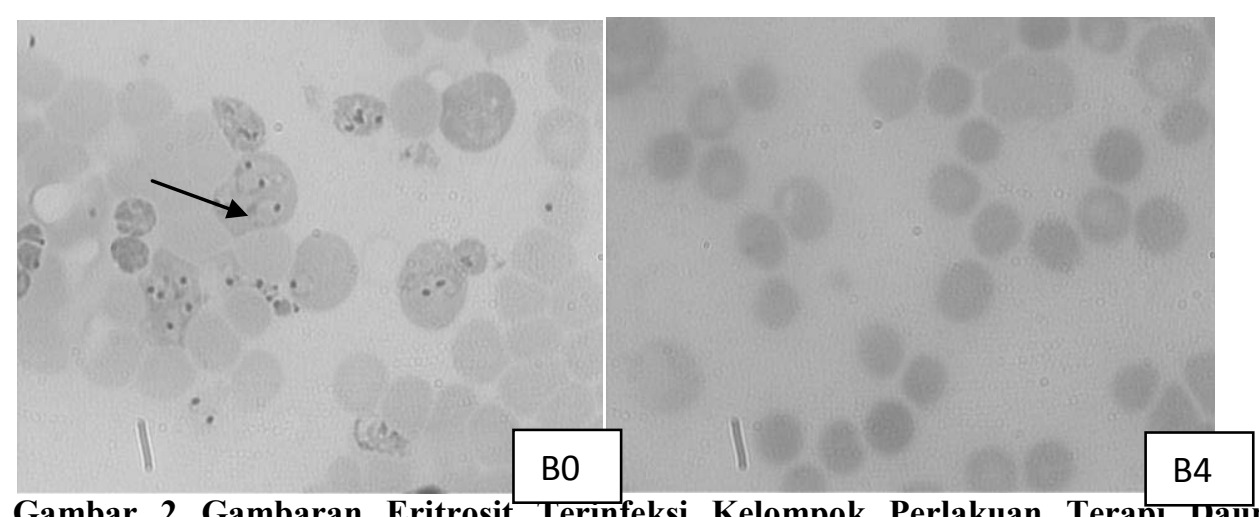

Gambar 2 Gambaran Eritrosit Terinfeksi Kelompok Perlakuan Terapı Daun Bunga Matahari 1 pada Hari ke-0 dan Hari ke-4 pasca terapi

Hapusan darah tipis mencit terinfeksi Plasmodium berghei dengan pengecatan Giemsa yang diterapi Daun Bunga Matahari 1, hari ke-0 sebelum terapi (B0) dan hari ke-4 (B4) pasca terapi. Gambar pada mikroskop perbesaran 1000x.

Pada hari ke-0 dan hari ke-4 pascaterapi dari Gambar 2 di atas terlihat adanya perbedaan gambaran hapusan darah tipis mencit yang terinfeksi Plasmodium berghei. Pada hari ke-0 tampak terlihat bentuk trofozoid dan bentuk skizon mature. Setelah dilakukan terapi selama 5 hari dengan daun bunga matahari dosis 1 didapatkan hapusan darah yang bersih dari parasit plasmodium berghei. Hal ini diperkuat dengan hasil perhitungan derajat parasitemia yang menunjukkan bahwa pada hari ke-3 dan ke-4 pasca terapi, derajat parasitemia telah mencapai $0 \%$.

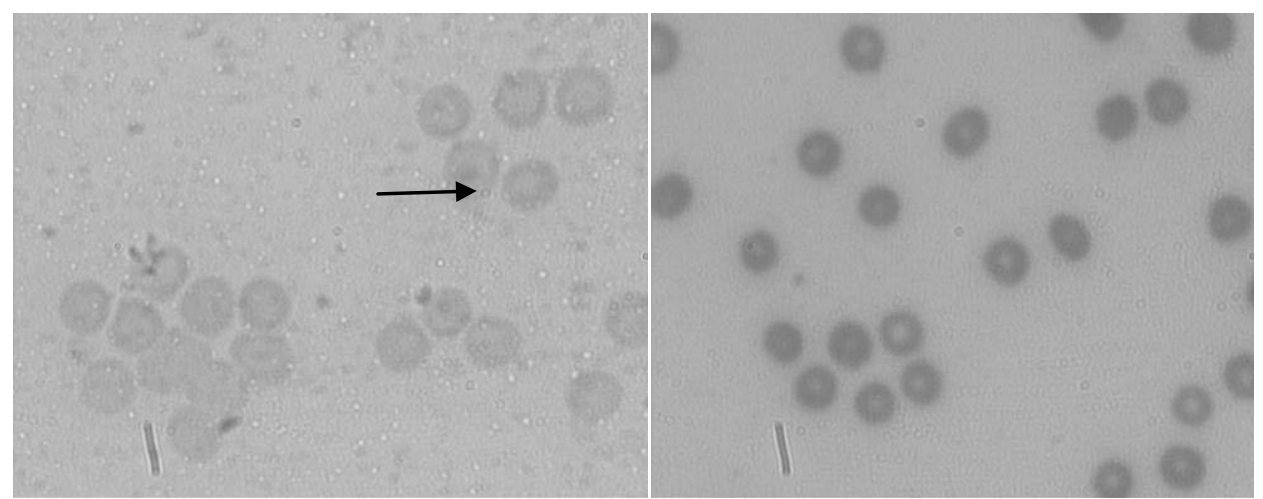

Gambar 3 Gambaran Eritrosit Terinfeksi Kelompok Perlakuan Terapi Daun Bunga Matahari 2, Hari ke-0, Hari ke-1, Hari ke-2, Hari ke-3, dan Hari ke-4

Hapusan darah tipis mencit terinfeksi Plasmodium berghei dengan pengecatan Giemsa yang diterapi daun bunga matahari 2, hari ke-0 sebelum terapi ( $\mathrm{C} 0)$, dan hari ke-4 (C4) pasca terapi. Gambar pada mikroskop dengan perbesaran 1000x.

Pada hari ke-0 dan hari ke-4 pascaterapi dari Gambar 3 di atas terlihat adanya perbedaan gambaran hapusan darah tipis mencit yang terinfeksi Plasmodium berghei. Pada hari ke-0 tampak terlihat bentuk trofozoid dan bentuk skizon mature. Setelah dilakukan terapi selama 5 hari dengan daun bunga matahari 
Uji Potensi Antimalaria Ektrak Diklorometan ...

dosis 2 didapatkan hapusan darah yang bersih dari parasit plasmodium berghei. Hal ini juga diperkuat dengan hasil perhitungan derajat parasitemia yang menunjukkan bahwa pada hari ke-3 dan ke-4 pasca terapi, derajat parasitemia telah mencapai $0 \%$. Efek yang di timbulkan pada terapi daun bungan matahari dosis 2 ini tidak jauh berbeda dengan dosis 1, pada penelitian ini menunjukkan bahwa dengan adanya peningkatan dosis1 ke dosis 2 tidak diikuti dengan peningkatanefek.

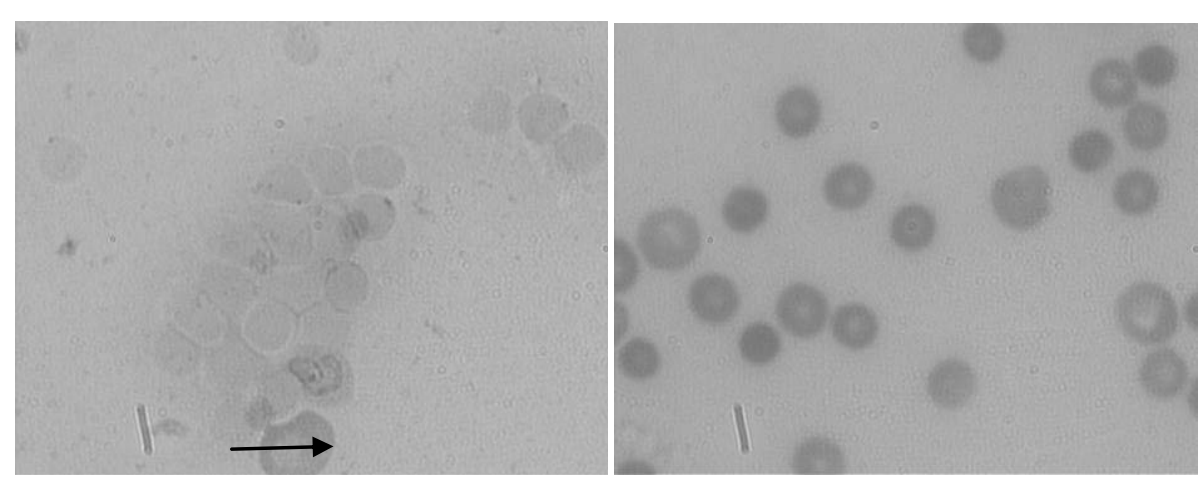

Gambar 4. Gambaran Eritrosit Terinfeksi Kelompok Perlakuan Terapi Daun Bunga Matahari 3, Hari ke-0 dan Hari ke-4 pasca terapi

Hapusan darah tipis mencit terinfeksi Plasmodium berghei dengan pengecatan Giemsa yang diterapi daun bunga matahari 3, hari ke-0 sebelum terapi (D0 dan hari ke-4 (D4) pasca terapi. Gambar pada mikroskop dengan perbesaran 1000x.

Pada hari ke-0 dan hari ke-4 pascaterapi dari Gambar 4 di atas terlihat juga adanya perbedaan gambaran hapusan darah tipis mencit yang terinfeksi Plasmodium berghei. Pada hari ke-0 tampak terlihat bentuk trofozoid. Setelah dilakukan terapi selama 5 hari dengan daun bunga matahari dosis 3 didapatkan hapusan darah yang bersih dari parasit plasmodium berghei. Efek yang ditimbulkan pada terapi daun bunga matahari dosis 3 ini menunjukkan lebih tinggi disbanding dosis 1 dan 2, hal ini diperkuat dengan data hari ke2 pasca terapi dimana pada dosis 3 ini derajat parasitemia telah mencapai $0,97 \%$ sedangkan pada dosis 1 dan 2 derajat parasitemia berturut-turut $2,51 \%$ dan 7,91\%. Pada hari ke-3 dan ke-4 pasca terapi derajat parasitemia telah mencapai $0 \%$

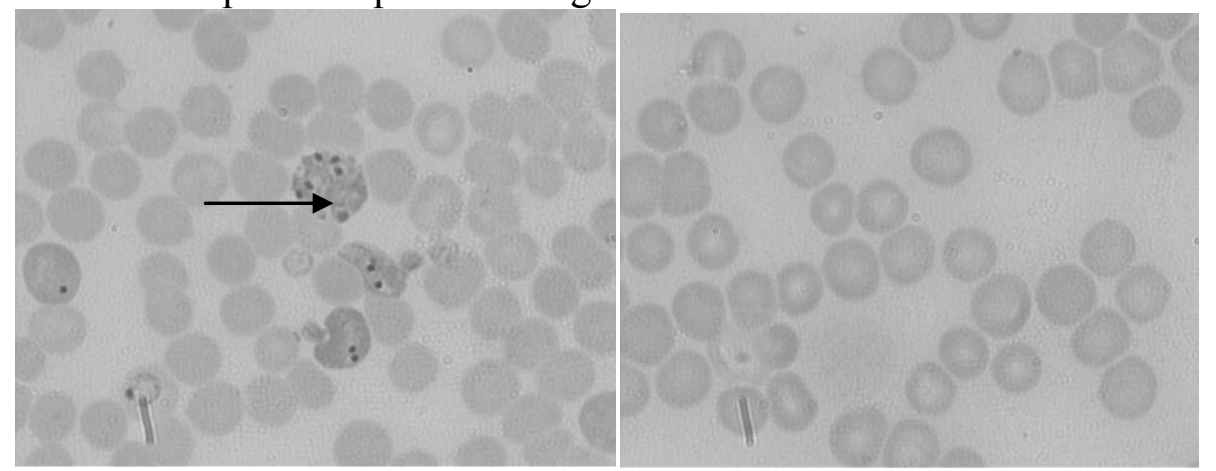

Gambar 5 Gambaran Eritrosit Terinfeksi Kelompok Perlakuan Terapi artemisin, Hari ke-0 dan Hari ke-4 pasca terapi

Hapusan darah tipis mencit terinfeksi Plasmodium berghei dengan pengecatan Giemsa yang diterapi artemisin, hari ke-0 sebelum terapi (D0 dan hari ke-4 (D4) pasca terapi. Gambar pada mikroskop dengan perbesaran 1000x. 
Pada hari ke-0 dan hari ke-4 pascaterapi artemisin dari Gambar 5 di atas terlihat adanya perbedaan gambaran hapusan darah tipis mencit yang terinfeksi Plasmodium berghei. Pada hari ke-0 tampak terlihat bentuk trofozoid dan bentuk skizon mature. Setelah dilakukan terapi artemisin selama 5 hari didapatkan hapusan darah yang bersih dari parasit plasmodium berghei. Hal ini di perkuat dengan hasil perhitungan derajat parasitemia yang menunjukkan bahwa pada hari ke-3 dan ke4 pasca terapi, derajat parasitemia telah mencapai $0 \%$.

Aktivitas antimalaria ekstrak dikolorometan daun bunga matahari pada penelitian inii diduga karena crude ekstrak diklorometan daun bunga matahari mengandung senyawa aktif yang dapat membunuh parasit plasmodium berghei. Diduga kandungan senyawa aktif pada tersebut adalah senyawa sesquiterpen.

Hal tersebut diperkuat oleh penelitian Stevenson et al (2005) bahwa berdasarkan hasil spektroskopi NMR telah ditemukan senyawa sesquterpen pada ekstrak diklorometan daun bunga matahari (Helianthus annus). Senyawa

sesquterpen telah diketahui mempunyai aktivitas antimalaria melalui mekanisme pembentukan radikal bebas dan menghancurkan komponen vital parasit sehinnga parasit mati. (Nurachman, 2003; Felix, 2006; Hommel, 2007). Sebagai contoh senyawa sesquiterpen adalah obat artemisin yang merupakan obat lini pertama dalam terapai antimalaria saat ini.

\section{KESIMPULAN}

Berdasarkan analisis data dan pembahasan, maka hasil Uji aktivitas antimalaria ekstrak diklorometan secara in vivo pada hewan coba dapat disimpulkan bahwa ekstrak diklorometan daun bunga matahari mampu membunuh parasit plasmodium berghei baik pada dosis $1(0,05 \mathrm{mg} / \mathrm{g} \mathrm{BB})$, dosis $2(0,5 \mathrm{mg} / \mathrm{g}$ $\mathrm{BB})$, dosis 3 (5 mg/g BB), dan pada masing-masing dosis tersebut telah diketahui bahwa derajat parasitemia mencapai $0 \%$ pada hari ke-3 dan ke4 pasca terapi. Analisis statistik menunjukkan bahwa aktivitas antimalaria ekstrak daun bunga matahari pada dosis $1(0,05 \mathrm{mg} / \mathrm{g}$ $\mathrm{BB})$, dosis $2(0,5 \mathrm{mg} / \mathrm{g} \mathrm{BB})$, dosis 3 (5 mg/g BB) berbeda bermakna terhadap control positif $(p<0,05)$.

E. SARAN

1. Perlu dilakukan identifikasi senyawa pada ekstrak dikloromethan daun bunga matahari

2. Perlu dilakukan uji untuk megetahui mekanisme kerja senyawa aktif antimalaria pada ekstrak daun bunga matahari

3. Perlu dilakukan uji toksisitas pada hewan coba untuk menentukan LD50 ektrak diklorometan daun bunga matahari

\section{F. UCAPAN TERIMAKASIH}

Penulis mengucapkan terima kasih kepada Lembaga penelitian dan pengembangan UIN maliki Malang yang telah mendanai penelitian ini.

\section{G. DAFTAR PUSTAKA}

Blazquez.S.,Thiberge.S.,Amino R., dan Ménard R., 2008. In vivo imaging of pre-erythrocytic forms of murine Plasmodium parasites dalam Methodes in Malaria Research $5^{\text {th }}$. Moll 
Uji Potensi Antimalaria Ektrak Diklorometan ...

Kirsten, Ljungstrom I, Petmann H, Scherf A, Wahlgren M. (ed) BioMalPar, Paris, France; 148152

Coutrier, F.2008.Propagasi Malaria In Vivo: Penggunaan hewan coba dalam Penelitian Malaria. Lembaga Biologi Molekul. Eijkman

Felix, 2006. Malaria, Penyakit Rawarawa yang Mendunia. http:// www.majalah-farmacia.com/ rubrik/one news.asp? IDNews $=7$ 7. Diakses tanggal 19 Oktober 2009.

Hasan, D, Rasio Efektifitas Biaya Obat Antimalaria Kombinasi Artesunate + Amodiakuin Dan Kombinasi Sulfadoksin + Pirimetamin Dalam Terapi Malaria Falsiparum, Disertasi Program Doktor UI, 2006.

Hommel M., 2007. Artemisin : natural, sintetik, atau rekombinan.

http://id.shvoong.com/medicineand-health/comparativemedicine/1858022-artemisininnatural-sintetik-ataurekombinan/.

Leiden University Medical Center (LUMC)., 2002. The Plasmodium berghei research model of malaria. Chapter 2 Introduction to Plasmodium berghei. http://www.lumc.nl/1040/researc h/malaria/model05.html

Macías FA; López A; Varela RM, Molinillo JMG; Alves A and Torres A . 1998. Bioactive Norsesquiterpenes from Helianthus annuus with Potential Allelopathic Activity, Phtytochemistry. 48,631-636

Macias F; Torres A; Galindo J; and Molinillo J. 2002. Bioactive Terpenoids from Sunflower Leaves. Phytochemistry. Volume
61, Issue 6, November 2002, Pages 687-692

Nurachman Z., 2005. Artemisin, Pembunuh Parasit Malaria (online),http:lunisosdem.oru/klipi ngdetail.php?aid2652\&caid $=\mathrm{I} \&=$ 56 diakses 7Mei2011

Phillipson J.D., and Wrigth CW., 1991, Antiprotozoal Agents from Plant Sourch, Planta Medica, 57 (Suppl.1), p.53-59

Sardjono T.W., dan Fitri L.E. 2007. Malaria, Mekanisme terjadinya Penyakit dan Pedoman Penanganannya. Malang: Lab Parasit FKUB

WHO.2011. World Malaria Report, 144.

http://www.malaria.org/malaria2 011.pdf

Spring O; Albert K and Gradmann W. 1981.. Annuithrin, a New Biologically Active Germacranolide from Helianthus annuus, Phytochemistry, 20, 1883-1885. 